\title{
8 Globalization, Civil Society and Islam: The Question of Democracy in Turkey
}

E. FUAT KEYMAN

It is a truism nowadays to propose that the world as we know it is in turmoil and that "all that is solid melts into the air." The historical conjuncture in which we live is in fact displaying significant transformations on a number of fronts and disturbing our sense of certainty in relation to our pursuit of the promises and ambitions of modernity. While the foundational grounds on which the project of modernity has been able to produce its hegemony are breaking down and/or melting, ambivalence appears to be the key notion for understanding the nature of the present. Antonio Gramsci's famous statement that "the old is dying and the new cannot be born: in this interregnum a great variety of morbid symptoms appear," although penned as early as the $1930 \mathrm{~s}$, captures and expresses eloquently the ambivalence that renders it difficult to pinpoint the direction of movement in our inter-societal and inter-national relations.

One of the sites at which the sense of ambivalence does, and continues to, occur is that of "the political" where "the crisis of essentialist universalism as a self-asserted ground" of political identity (Laclau 1996: 2) has meant the emergence of a discursive void in which particularistic conflicts have begun to increasingly dictate the mode of articulation of political practices and ideological/discursive forms in national and global relations. Inasmuch as the crisis of universalism does not rule out its existence, the sense of ambivalence in the present generates the mutual effort of sameness and difference to cannibalize one another and thus to proclaim their successful hijacking of the twin Enlightenment ideas of the triumphantly universal and the resiliently particular (Appadurai 1990: 17).

This politics has a name: the politics of identity. Debates over multiculturalism and citizenship in Western Europe and North America, ethnic conflict in the Balkans, the rise of Islamic fundamentalism in the Muslim world, and the increasingly apparent crisis of national identity, to name a few, while being different manifestations of the politics of identity, are also all indicators of the ambivalent nature of the present.

It would certainly be a mistake, however, to celebrate such ambivalence or by defining it as positive thereby to establish an essential link between the 
politics of identity and the democratic rearticulation of the political. Instead, we must recognize the ambivalent nature of the present. While constituting grounds for what William Connolly (1996) calls "the ethos of pluralization," it can easily give rise to communitarian attempts at renouncing a democratic vision of society, as in the cases of ethno-nationalism, meta-racism and religious fundamentalism, all of which are examples of the politics of identity. It is in this sense that a critical analysis of the present is of utmost importance. It will help to mediate the relation between the universal and the particular in a way that makes the democratic rearticulation of the political possible.

This chapter provides a critical analysis of the ambivalent nature of the present by focusing on one specific case where it has taken the form of "the dilemma of cultural identity on the margin of Europe," namely the Turkish social formation (Keyder, 1993a).

The present political landscape in Turkey exemplifies very clearly the tension between the universal and the particular. At stake is the clash between a secular national identity as the bearer of cultural homogenization and the revitalization of the language of difference through the rise of Islam, the re-emergence of Kurdish nationalism in organized form, and the feminist movement that has been effective in putting the "women question" at the center of the process of "rewriting Turkish historiography." Despite significant differences among them, especially as to their political agenda, ${ }^{2}$ all these movements directly challenge the unifying conception of cultural identity which is the basis on which secularist Turkish nationalism reproduces itself.

Given the limited scope of this chapter, I will take as the organizing reference point of my analysis the rise of Islamic identity and the concomitant construction of a polarity in Turkish political life, that of 'secular modernism versus Islamic traditionalism.' This polarity reveals the paradox of the post1980 coup period of Turkish modernization: a paradox which was marked by two seemingly-contradictory processes. The first is a neo-liberal structuration of the state/economy interactions. The second is the emergence of Islam as an increasingly strong political force, resulting in the success of the Welfare Party that won the general election of 1995 and then formed the coalition government, thereby becoming the ruling party of what is defined as a strictly secular society.

This paradox was crystallized when the Supreme Court decided in 1997 to close down the Welfare Party and ban for five years its power bloc, including the party's leader (Necmettin Erbakan), from politics. The decision was justified on the ground that the party's activities were clearly intended 
to denounce the modern, secular, and democratic regime of the Turkish Republic. Thus a party that had come to power through democratic elections was shut down in the name of democracy and modernity.

The Supreme Court's decision was based on the belief that secularism constitutes the crucial link between democracy and modernity, and therefore any anti-secular attempt, which should be seen as anti-modern and antidemocratic by definition, poses a threat to the regime, even if its condition of existence is embedded in multi-party parliamentary life. Although the decision was "legal" in the sense that it was grounded on the Constitution, its "legitimacy" has been subject to intense debate, because it gave priority to the secular regime over the principle of democratic pluralism, and even more importantly because it did not alter the sociological fact that the Islamic identity still constitutes a strong political and symbolic force in Turkish socio-political life. ${ }^{3}$

These two paradoxical developments - the neo-liberal restructuring of politico-economic life and the resurgence of Islam - cannot be understood unless we locate them in a broader world-historical context. Following Santos' analysis of globalization(s) (Chapter 10 in this book), I will argue that because the multiple processes of globalization have the potential of undermining the "national/territorial" constitution of social action, they function as the world-historical context in which state-society relations of post-1980 Turkish modernization is embedded.

With this perspective, it is possible not only to recognize the importance of the global-historical context, but also to analyze Turkish modernization without falling into a sort of reversed-Orientalist trap that would treat Turkey as a "unique experience." More specifically, I will show that post-1980 Turkish modernization exemplifies, in a specific way, what Santos calls "the weak state consensus." In particular, the weakening of the state, derived from the logic of the neo-liberal restructuring of the economy, produces a "discursive space" for the emergence of Islamic resurgence as a powerful political and symbolic force, rather than its democratization.

However, to embed Turkish modernization in a global-historical context as a unit of analysis is not to ignore its particularity, its unique historical features. To understand the seemingly paradoxical connection between neoliberalism and Islamic resurgence, as well as its manifestation in "the weak state consensus," it is necessary to analyze historically, as a derivative discourse of Western modernity, what I call the dilemma of Kemalist nationalism. I will argue, in this context, that the rise of Islamic identity is intrinsically bound to the crisis of Kemalist nationalism and that Kemalism in this sense should be regarded as integral rather than external to the 
increasing politicization of Islam. It is in this context that we can understand the linkage between the universal (the post-1980 acceptance of the triumph of liberalism) and the revitalization of the language of difference as a resistance to the secular national identity.

It is, therefore, necessary, as a first step, to delineate the way in which the dilemma of Kemalist nationalism comes into existence. To do so, I will provide a critical reading of the dominant paradigms of Turkish modernization, which will allow me to suggest that Kemalism should be seen as a project of modernity. Secondly, I will analyze the way in which as a project of modernity Kemalism becomes the hegemonic mode of governing society. I will demonstrate how Kemalism reproduces its hegemony by articulating itself in its alternatives, especially as far as their totalistic and organic visions of society are concerned. Thirdly and finally, I will explore the possibilities of democratic rearticulation of state/society relations in Turkey.

\section{Kemalism and Modernity}

As Feroz Ahmad (1993) correctly observes, "Turkey did not rise phoenix-like out of the ashes of the Ottoman Empire. It was 'made' in the image of the Kemalist elite which won the national struggle against foreign invaders and the old regime." The making of modern Turkey raises an interesting question for students of social change, since neither the class-based understanding of revolution nor post-colonial state-oriented development theory can be used as an explanatory model. This is precisely because Turkey had never experienced "colonialism" in the real sense of the term. Nor had its national independence been produced by a social class. However, just as in postcolonial states, the history of the making of modern Turkey has been that of Westernization, conditioned by what de Ferro calls "the will to (Western) civilization" (de Ferro 1995).

In the process of this "making" of modern Turkey, the Kemalist elite sought to "reach the contemporary level of civilization" by establishing its political, economic, and ideological prerequisites, such as the creation of an independent nation-state, and fostering industrialization and the construction of a secular and modern national identity. The Kemalist elite thus accepted the universal validity of Western modernity as the way of building modern Turkey. In this sense, the making of Turkey was based both on gaining independence from Western imperialism and on accepting its epistemic and moral dominance. 


\section{Two Paradigms of Turkish Modernization}

Seeing that the Kemalist will to civilization is embedded in Western modernity requires a new theoretical framework that goes beyond existing paradigms of Turkish modernization. Such a view provides us with a significant clue for understanding the increasing strength and importance of the "Islamic turn" in politics.

Generalizing only a little, one can discern in the available literature on Turkish modernization the dominance of two paradigmatic readings of Kemalism - those of modernization and identity. It should be pointed out from the outset that these paradigms are not unique to the Turkish experience, but can be found elsewhere, such as in the modernization experiences of Japan, Egypt and Peru. My intention here is only to point out that there is a need to understand the Turkish experience as "a project of modernity," in order to see both the hegemony of Kemalism and its constitutive role in the process of the resurgence of Islamic identity.

The modernization paradigm situates the Kemalist will to civilization in a transition from Gemeinschaft ('community') to Gesellschaft ('society'). However thinking of it as such a transition has different consequences, depending on the version of the modernization paradigm employed. Political modernization sees this transition as a process of nation-building, in which the nation-state is taken to be the unfolding essence of modernization. The making of modern Turkey then becomes a process of political modernization which, through nation-state building, creates a modern nation while the Ottoman past is represented as a backward, traditional society. Whereas political modernization sees this transition as a positive break from the past and a move forward, economic modernization in line with dependency theory considers it to be a new form of "peripheralization" and dependent capitalist development which started with the integration of the Ottoman economy into the world capitalist system in the 19th century.

However useful these visions are for accounting for the making of modern Turkey, the modernization paradigm is limited in its scope and reductionist in its methodological procedures. It is limited as it attempts to analyze its subject-matter by privileging a certain type of social interaction as "the prime mover" of social change. Thus, either nation-state building or economic development is considered to be a process that produces a systemtransforming effect in the formation of social interactions, which results in a lack of attention paid to the role of other processes, thereby neglecting their transformative capacity. The modernization paradigm is also reductionist insofar as it attributes (in a Hegelian fashion) to society the quality of an 
expressive, constituting totality in which the conditions of existence of various social interactions are regarded as necessarily linked to and determined by the unfolding essence.

In contrast to the modernization paradigm, the paradigm of identity seeks the essence of the manner in which Kemalism approaches the question of national identity. Two alternative accounts of the essence are produced in this paradigm, which are derived from two different interpretations of the meaning that the notion of "Turk" connotes in cultural practices in the process of the making of modern Turkey. On the one hand, there is a tendency to interpret Kemalism as a nationalist discourse whose understanding of national identity was "cultural" in its essence. In this sense, the notion of Turk is referred to as a "meta-identity" that is situated above and beyond "the difference principle," and thus operates as a point of sameness at which the claim to the impartiality and the universality of the state is constructed. On the other hand, there is an interpretation of Kemalism on the basis of the difference principle, claiming that the notion of Turk is framed to a large extent by and within an ethnic-based understanding of national identity. In this sense, Kemalism is regarded as an ethnonationalist discourse whose aim was to impose a secular and ethnicallyessentialist vision of modern Turkey on what Kevin Robbins (1996) terms "the other but real Turkey."

Despite the fundamental difference between them, these two modes of interpretation share two highly problematical epistemological and methodological gestures. The first concerns the historicist nature of the paradigm of identity, insofar as its search for discovering the true essence of the Kemalist vision of national identity rests upon an attempt to read the past in terms of the present (Dean 1994: 9). This is so, because this paradigm is not attempting to analyze Kemalist nationalism in its own right or in its own context, but rather to find a legitimizing ground for the competing political discourses of the present political landscape over such issues as political Islam, the Kurdish question, laicism, ethno-nationalism or the crisis of representation in state/society relations.

The second problem concerns the essentialist nature of the paradigm. The notion of identity employed assumes that each individual or collectivity possesses a fixed, coherent, and totalizing self. This means that each identity involves an unfolding essence which makes it a self-contained, selfreferential and self-propelling presence, and therefore that the variations that occur historically in terms of the identity formation of individuals or collectivities do not alter the essence of their identities. The paradigm of identity thus acts as an essentializing gesture that ignores the relationality, 
multiplicity and historically constructed nature of identity formation. As such the Kemalist understanding of national identity becomes a universalizing discourse with a fixed, unchanging and original identity.

\section{Kemalism as a Project of Modernity}

There is, then, a need to "go beyond" these paradigms so as to recognize the crucial fact that the Kemalist will to civilization is intrinsically linked to and operates within the discursive horizon of global modernity. The Kemalist elite's will to civilization was not simply an economic or a political modernization. Nor was it based upon an attempt to create a national identity. As will be apparent later, it was much more complex and at the same time ambiguous than presented by these paradigms. To understand this however requires regarding the Kemalist will to civilization as a project of modernity which was premised on the equation of modernity with progress, that is, on the making of a modern nation through the introduction and the dissemination of Western Reason and rationality into what were regarded as traditional and backward social relations. It is in this sense that the connection between Kemalism and modernity, ignored by these paradigms, needs to be explored, in order to provide an adequate account of the dilemma of Turkish nationalism.

In his analysis of the making of modern Turkey, Mardin (1994a) argues that the meaning of Kemalism lies in "the conceptualization of the Turkish Republic as a nation-state in its fullest form," and finds its expression in its constant effort to create a modern nation. Mardin's seemingly straightforward and commonsensical argument in fact carries with it a number of crucial insights for a more adequate understanding of Kemalism. Firstly, to think of Kemalism as "an act of conceptualization" is to present it as a "project" of creating a nation on the basis of a set of epistemological and normative procedures. Secondly, to argue that Kemalism means the conceptualization of the Turkish Republic as a nation-state in its fullest form is to recognize that it constitutes a project of modernity; a project of creating a modern nation that "accepts the claim to universality of the 'modern' framework of knowledge" (Chatterjee, 1986:11). Thirdly, to think of Kemalism as a project of modernity is to recognize its modus operandi as a social engineering project that aims at creating a modern nation in a social formation where the material and institutional availability of the conception of a modern nation as a nation-state in its fullest form was absent.

These three points also indicate that Kemalism is a nationalist discourse that operates as a "will to civilization" by producing at the conceptual level 
a boundary between what is civilized and what is uncivilized. Thus, by accepting rational thinking and rational morality as the way of becoming modern, Kemalist nationalism is directed to reaching the level of civilization, that is, the making of modern Turkey as nation-state in its fullest form.

\section{Kemalism and the Will to Civilization}

According to Mardin (1994b), the conceptualization of the Turkish Republic as nation-state manifests itself in: (i) the transition in the political system of authority from personal rule to impersonal rules and regulations; (ii) the shift in understanding the order of the universe from divine law to positivist and rational thinking; (iii) the shift from a community founded upon the elitepeople cleavage to a populist-based community; and (iv) the transition from a religious-community to a nation-state. These transitions are regarded by Mustafa Kemal as the pre-condition for the possibility that "Turkey would live as an advanced and civilized nation in the midst of contemporary civilization" (Ahmad 1993: 53). It is in this context that the Kemalist elite attempted to remove from political discourse the notion of an Islamic state, the existence of which was regarded as the main cause of the perpetuation of the backwardness of Turkey. Thus, the foundation of a modern nation-state was seen as the key element of the will to civilization.

For the Kemalist elite, modern Turkey could thus possess secularity and rationality, employ Reason to initiate progress, and establish a modern industrial economy, thereby fostering the processes of industrialization and modernization. In a Weberian fashion, the purpose of political power was considered to be to "carry out a social and economic revolution without which the political revolution would dissipate" (Ahmad, 1993:72). This means that for the Kemalist elite, political power was not reducible but interrelated to the economic.

The rationalization of the political and the rationalization of the economic were seen to be relational processes whose reproduction could be made possible through the construction of a national identity. In this respect, the Kemalist will to civilization was based upon an articulation of modernity (Reason) and capitalism (Capital) into Turkish society through the construction of a modern nation-state.

As Metin Heper (1985) points out, the idea of the state employed by the Kemalist elite was by no means abstract: rather it was derived from a reaction to two fundamental problems which they saw as key to the decline of the Ottoman empire. First, the Ottoman state was identified with the personal rule of the sultan, which eventually led to its inability to compete with the 
European nation-state system (Heper 1985: 49). Second, the Islamic basis of the Ottoman state was regarded as the primary obstacle to progress in Ottoman society. For the Kemalist elite, there was therefore a need to create a nation-state distinct from the person of the sultan and secular enough to reduce Islam to the realm of individual faith. This meant a reconstruction of the idea of sovereignty as national rather than popular sovereignty. Underlying this, as Heper argues, is the association of the Kemalist elite with the Durkheimian conception of the state as the agent of rationality. The state is thus viewed not as an arbitrary institution nor as an expression of class interest but as an active agent that, while taking its inspiration from the genuine feelings and desires of the nation, shapes and reshapes it to "elevate the people to the level of contemporary (Western) civilization" (Heper 1985: 50). Therefore, the Kemalist idea of the state was embedded in the question of how to activate the people towards the goal of civilization, that is, how to construct a national identity compatible with the will to civilization.

Ernest Gellner considers the Kemalist idea of the state to be a commitment to political modernity, which sees the modernization of the polity and society as linked to the state. This commitment "constitutes its legitimation and is itself in turn justified by the strength which it bestows on the state" (1994: 83). However, it would be wrong to view the Kemalist idea of the state as institutional. As Bobby Said has correctly pointed out, the Kemalist elite:

took seriously the Weberian answer to the riddle of the 'European miracle'; that is, that the reasons behind Western advancement could be located precisely in Western cultural practices. Kemalism understood modernization not just as a question of acquiring technology, but as something that could not be absorbed without a dense network of cultural practices which made instrumental thought possible (1994: 269).

This means that the commitment to political modernity has to be supplemented with a set of cultural practices in order to ground the articulation of reason and capital via the nation-state, that is, via the institutional and discursive construction of national identity. It is for this reason that the Kemalist elite initiated a set of reforms needed to be imposed from above to "enlighten the people and help them make progress" (Heper 1985: 51). ${ }^{4}$ These reforms were designed to equate the general will with the national will, thereby creating a vision of society not as an aggregation of different interests, but almost in a Platonic vision as an organic totality 
organized around the principles of division of labour and the reciprocity of needs.

Republicanism, nationalism, etatism, secularism, populism, and revolutionism-reformism (from above) were the six principles of the act of governmantality. Republicanism defined the nation-state as "impersonal rule," which was contextualized as national sovereignty through nationalism. Thus, these two principles constituted the political image of the Kemalist elite. Etatism was designated to foster capitalist industrialization through import-substitution policies carried out by the state, and gave expression to the politico-economic logic of the Kemalist elite. These three principles indicate the acceptance of the dominance of the West. They also indicate the significance of nation-state building for nationalist discourse. What gave specificity to Kemalist nationalism, however, was its populist character, its rejection of the West as a class-based social formation. Populism meant, in the Turkish context, the affirmation of the non-class character of Turkish society. As Toprak put it:

Kemalist populism defined 'people' as an organic unit composed of professional groups rather than classes. As opposed to class solidarity, populism emphasized the solidarity of the whole nation. There were no classes, hence no privileges based on class differences, and hence no class conflict (Toprak 1987: 218).

In this sense, Kemalist nationalism was an attempt to base its will to civilization on populism rather than liberalism, whose reflection on the economic level was the replacement of laisser-faire with etatism. The last two principles, secularism and reformism, served to construct a national identity compatible with republicanism, nationalism, and etatism, and at the same time to concretize populism and its appeal to organic unity into the identity of the individual subject. They were also central to the determination of who is included in and who is excluded from the organic unity. $^{5}$ It is through secularism that Kemalist nationalism initiated its boundary-producing performance between the Self and the Other, thereby giving a concrete form to its populist-based creation of the national identity. Hence, the national identity was meant to be an organic unity of the secular non-class based identity which necessarily involved the subjugation of its Other, that is the Muslim identity. 


\section{Kemalism and the Specificity of the Political}

It is striking that the basis of Kemalist nationalism was identification of popular sovereignty with national sovereignty within the context of the organic conception of society, derived not from "to whom sovereignty belonged" but from "to whom it did not belong" (Heper 1985: 45). In other words, embedded in the making of modern Turkey was, to use Foucauldian terminology, the governmentality of nationalist discourse that practiced inclusion and exclusion by creating identity in relation to difference, and by freezing the Other, the Islamic identity, into history. ${ }^{6}$

By assuming a self-identity as the primary agent of progress, the Kemalist elite thus came to locate secularism within binary dichotomies such as progressive versus conservative, modern versus traditional, and progress versus backwardness. ${ }^{7}$ It is in this sense that, as Toprak has observed, up until the 1961 constitution which liberalized political discourse according to the multi-party system, Kemalist nationalism was able to manage, especially with the aid of its non-class based populist ideology, to define the political landscape on the basis of the secularist-anti-secularist axis, as well as to categorize political forces in accordance with their stand on secularism (Toprak 1987: 219). Secularism, in this context, served not only to reinforce the image of the Kemalist elite in the making of modern Turkey but also to create a secular national identity by excluding and marginalizing the Islamic identity.

It should be pointed out that the Kemalist preoccupation with secularism and the marginalization of Islam was not without basis. At least three factors are worth emphasizing. ${ }^{8}$ First, insofar as Islam is characterized by the incorporation of the political into the religious realm, it constitutes a radical alternative to both secularism and secular political authority. Second, Islam is conducive to the creation of an alternative political community and identity on the basis of divine revelation, and in this respect is able to have a unifying appeal to the masses as a source of common identity. Third, "the Islamic impact on Ottoman social and political life serves as a reminder that Islam can indeed be a base of resistance to modernization efforts that follow the Western pattern" (Toprak, 1987: 220). These three factors constitute the very basis of the sensitivity of the Kemalist elites on the issue of Islam and their attempt to impose a strict version of secularism on Turkish society.

However, such strict secularism did not prevent Islam from remaining a significant agent in the formation of social and political life in modern Turkey. While being excluded as the Other of the national identity, Islam has been a significant "symbolic system" providing meaning to human 
existence and thereby forming the bases of both individual and community identity. In other words, while Kemalist nationalism was successful in transforming Islam into "the position of a purely individualist faith," "the transformation of the Ottoman subject into a citizen of the Turkish republic proved much more complicated than de jure acceptance of equal treatment before the law" (Toprak 1987: 221). It was Islam that caused the complication by providing religious group norms and values by which the individual subject can be integrated into a political community that presents itself as able to supersede an abstraction like nation and national identity.

Thus, strict secularism was only a solution to keep Islam in its place as an individual faith. Its attempt to construct a national identity did not lead to excluding Islam from the symbolic construction of identity. In fact, from the beginning of the making of modern Turkey, the process of identity construction was determined by the discursive struggle between the will to civilization through secularism and the will to tradition, a will to traditional political community based on Islam. As a symbolic system, while Islam did not function as a political force able to mobilize the masses against the Kemalist elite, it did allow interpellation of the individual subject as a Muslim.

By functioning as a boundary-producing practice, nationalist discourse with its six operative mechanisms - republicanism, national sovereignty, etatism, populism, secularism, and reformism - enabled the state to successfully exclude the Islamic Other from the political landscape, to subjugate it to secular political discourse, and to prevent it from becoming a political actor. It can be argued in this respect that the Turkish nation-state did not have an ontological status apart from the above-mentioned acts that constituted its reality and therefore that its identity was performatively constructed. ${ }^{9}$

This theoretical extrapolation provides a crucial insight for an adequate understanding not only of the relegation of Islam to the position of an individual faith, but also, and more importantly, of the rise of the Islamic identity in the post-1980 coup period in Turkey. If Kemalist nationalist discourse helped reproduce the will to civilization as a whole as a way of keeping Islam in its place, the very crisis of such discourse is also central to the rise of the Islamic identity in Turkey. My goal is not to establish a causal linkage between the two phenomena, but to emphasize that the crisis of the former provides "a context," or "a discursive space" for the possibility of the transformation of Islam into a political factor and of Islamic identity into a radical alternative to the secular national identity. Implied here is also the suggestion that the 1980 military coup brought about a radical transformation 
of the Turkish political landscape, one as fundamental as the post-1923 nation-building period.

Before focusing on the post-1980 coup period, however, it is important to explain briefly how Kemalist nationalist discourse remained hegemonic despite the emergence of the alternative visions of the Turkish political landscape after World War II.

\section{The Continuance of Hegemony in the Changing Political Landscape}

Although, especially since the transition to the multi-party system (1945) and the rise of the New Left (1960s), it was no longer possible to define the Turkish political landscape on the basis of the secularist versus antisecularist axis, Kemalist nationalism can be said to have maintained its hegemony over Turkish political and social life. With the multiparty system, the emergence of the liberal vision of Westernization and modernization presented a serious alternative to the Kemalist principle of etatism and populism. At the same time, with the rise of the New Left, the emergence of the socialist vision challenged the non-class based populist image which had been used to define Turkish society as an organic totality. However, these challenges did not lead to a significant transformation in the construction of state identity. Nor did they give rise to a radical rupture in the performativity of Kemalist nationalism in giving meaning to the making of modern Turkey. In fact, both liberal and New Left political discourses functioned in relation to Kemalist nationalism and, to a significant extent, took as given its will to civilization, thus employing its principal modus operandi, that is, creating the general will "in the name of the people."

Several reasons explain the continuing hegemony of Kemalist nationalism. First, neither liberal nor New Left discourses constituted an alternative to the essentialist posture of Kemalist nationalism towards secular national identity. Instead, they affirmed and reaffirmed such essentialism and its practice of inclusion and exclusion. For this reason, to the extent that they pursued "in the name of the people" and "revolution/reform from above," they were unable to construct an alternative subjectivity to the secular national identity. ${ }^{10}$ The liberal critique of Kemalism and its monopartism, which was put forward by the Democratic Party, was intended to reconstruct the political landscape as a multi-party democracy. However, this critique was meant only to secure the representation of the private sector which the Democratic Party saw as the precondition for the modernization of Turkish society (Ahmad 1993: 103-120). In this sense, liberal discourse, while presenting itself as an alternative to Kemalist nationalism, functioned by 
accepting its two fundamental characteristics, namely those of the equation of modernity with progress and the need to construct a rational self as the agent of modernization. Likewise, leftist formulas such as national democratic revolution, which were espoused by the Workers' Party of Turkey and its counterpoint the Yön (Direction) movement during the 1960s, were derived from what Ahmet Samim called "a left-Kemalist substitutionalism" whose aim was to resist imperialism and to lead Turkey democratically "on behalf of the workers and peasants - for the people, in spite of the people" (Samim 1981: 155).

Secondly, both liberal and New Left discourses were intrinsically bound with modernity, and in this respect they were by no means a challenge to the Kemalist will to civilization. Both accepted the validity of the Kemalist notion of the state as the privileged agent of rationality the existence of which was central to the process of modernization. Both provided a reading of Turkish society through the lenses of the state by assuming that it is the state that shapes and reshapes social relations. The liberal critique of Kemalism was therefore only partial: it was directed exclusively to the strict etatist and populist policies by which the state coped with the problems of capitalist industrialization. On the other hand, the New Left critique of Westernization as imperialism and its characterization of Kemalist nationalism as an agent of the subordination of Turkey to Western imperialism was derived solely from the rejection of capitalism. In other words, while capitalism was being rejected as a mode of production generating inequalities and uneven development, the modernity aspect of the will to civilization, that is, its epistemic dominance and its Reason, was accepted as given. However, as noted, it is not capitalism but Western modernity upon which the Kemalist will to civilization was based.

Thirdly, although etatism was subjected to serious criticism, importsubstituting industrialization remained as the motor of industrialization after the transition to the multi-party system. Whereas its counterparts in Latin America faced military coups due to the deepening crisis of importsubstituting industrialization (such as Brazil, Argentina, and Chile), the Turkish economy during the 1960s, experienced an economic boom. For this reason, liberal discourse, though critical of etatism, was linked with importsubstituting industrialization. According to Keyder, an explanation for this long-lasting dominance of import-substituting industrialization as a form of economic nationalism can be found in the fact that nationalism was a site of global capitalism, a way of reproducing it, and therefore did not present a contradictory tendency. This made it possible for Kemalist nationalism to foster industrialization not against but in concord with global capitalism 
(Keyder 1987 and 1993b). For Keyder, it was only when global capitalism was formed by the liberal market logic that nationalism became a contradictory discourse to the systemic logic. The point here is that the transition to a multi-party system did not involve the replacement of the economic logic. Hence, Kemalist nationalism was menaced by industrialization policy. ${ }^{11}$

\section{The Crisis of National Identity and the Politics of Difference}

The 1980 coup brought a radical rupture, the impact of which was deeply felt at every level of Turkish society. At the economic level, the goal of industrialization was decisively shifted from import-substitution to exportpromotion, and much more emphasis was placed on market forces. It should be noted, however, that the primary agent of this shift was the state and that it was primarily a political act, or an outcome of political decisionism, which had no specific class belonging. As Eralp has observed:

those who were supposed to be the main actors in the different development policies [that is, export-oriented development] were the same industrialists who, with substantial support from the state, had been transformed from merchants into industrialists in the 1950s. Again, it was through state support that import substituting industrialists were transformed into exporters in the years following 1980 . Thus, contrary to belief, export promotion did not lessen state intervention, it merely changed its direction (Eralp 1990: 221).

State intervention was directed toward the privatization and neoliberalization of the economy, the creation of a new trade regime, and the employment of new modes of foreign policy in search of markets for export. It was also directed, similar to the new right policies of Reaganism and Thatcherism, at the managerial and technocratic reconstruction of political discourse to shape state-society relations on the basis of technicalinstrumental rationality that was to operate by privileging efficiency over social welfare. ${ }^{12}$ The crucial point to be emphasized here is that since export-promotion was the form of adaptation to the international division of labour, the shift in industrialization was in fact the transformation of the Kemalist will to civilization to civilization via laisser-faire, which was fundamentally contradictory with the Kemalist image of the organic state. That is to say, while serving to create a secure ground for the liberal restructuring of economic life, the 1980 coup ironically created a ground for 
a new idea of the state which was to replace the Kemalist republican populist state, the existence of which it was supposed to protect. Indeed, the 1980 coup resulted in the transformation of state identity from radical secularist to what Birtek and Toprak term neo-republicanism. An appeal to national and ideological uniformity was no longer dictated by the basic principles of Kemalist nationalism. Instead, by incorporating "Islamic discourse and implicitly [taking] umma [a community of believers who are united by the same (Islamic) faith] as its model of social organization," and also by abandoning "the radical secularism of the early republic" to secure its popular support and to open up the domestic market to Islamic capital, the post-1980 military regime weakened the very conditions of existence of Kemalist nationalism and the republican state (Birtek and Toprak 1993: 197). ${ }^{13}$

This was the specific nature of the "weak state consensus," first established by the military regime and then consolidated by the neo-liberal Mother Land Party government. Its particularity derived from the fact that although it was embedded in the logic of global capital and global modernity, it also opened itself to Islamic discourse and made use of it to the extent that it contributed to the resurgence of Islamic identity as a strong political force.

The use of Islamic discourse and its notion of umma was considered by the military regime to be a temporary and short-term pragmatic strategy to restructure the political and to restore the performative power of the Kemalist republican state. ${ }^{14}$ However, such a contradictory move led to unintended consequences. The first was that in the 1983 national election, which was the beginning of civilian rule, the neo-liberal Mother Land Party came to power despite the resistance of the post-1980 coup military regime and its publicly announced support for the Nationalist Democracy Party which was formed as the "state party" of the post-1980 coup regime. This result indicated, on the one hand, the crisis in the performance of the state to carry out the Kemalist will to civilization. On the other hand, it gave rise to the construction of a new state identity whose performative acts are no longer bound with radical secularism and the populist conception of the people but are embedded in laisser-faire market ideology, the managerial and technocratic understanding of the state, and the dissemination of the discourse of economic rationality within Turkish society. Hence, the post1980 coup period characterized not only the export-oriented integration of Turkish economy into global capitalism but also the deepening of the crisis of Kemalist nationalism to reproduce its hegemony.

Secondly, the regime's temporary and pragmatic appeal to Islamic discourse to create ideological unity has become one of the enabling factors for the emergence and re-emergence of Islamic organizations within both 
state and civil society as a political party or as tarikats (the religious brotherhoods) and also for their increasing strength within the Turkish political landscape.

In other words, the primary aim of the 1980 coup to depoliticize the society and to restructure political activity contained in itself a fundamental contradiction. Notwithstanding its overtly Kemalist orientation, the coup opened a discursive space for the revitalization of the language of difference, a discursive space which created a possibility for the marginalized and silenced identity to surface and express its resistance to the national secular identity as the privileged modern self. More concretely, and even ironically, while the military coup targeted the left, actually unthreatening to the Kemalist identity, it was fostering discourses aimed primarily at dismantling that identity. Thus, depolitization brought into existence once again the secularist versus anti-secularist axis. ${ }^{15}$

Consequently, it can be argued that the rise of the Islamic identity in Turkey is one outcome of the "weak state consensus," in which neoliberalism went hand in hand with Islamic discourse. It is for this reason that besides its relation to "the newly emergent upwardly mobile middle classes which were organized within the newly laid avenues that the anti-left politics of the 1980s created" (Birtek and Toprak 1993: 193), it emerged, in a discursive fashion, in a context in which Kemalist nationalist discourse was facing a serious identity crisis and its will to civilization was no longer capable of limiting the imagination of political community within the horizon of modernity. More importantly, it emerged at a time when the total exposure (through the increasing modernization of economy based on the exportoriented development) of Turkish society to global modernity was radically transforming identity-conceptions and social configurations into ambivalence and uncertainty. Islamic discourse acted successfully as an articulating principle of resistance to such uncertainty by identifying ambivalence with global modernity and certainty with community, that is, with a turn to religion.

The simultaneous rise of neo-liberalism and Islam, in this sense, should be understood as a product of the historical dilemma of nationalism as a derivative discourse and its increasing inability to demarcate the boundary between identity and difference. This means that the rise of Islamic identity is not simply a "revival" of an essential and coherent identity which, although being marginalized by Kemalist nationalism, was always and already operative in civil society. Rather, Islam appeared to be one of the (indeed, significant) articulating elements of difference by which to construct an alternative subjectivity to the unifying vision of national identity, in an 


\section{Globalizing Institutions}

historical context where the depolitization of social relations and the reorganization of political life in a non-participatory mode unintentionally created the possibility of thinking of political community outside the terrain of Kemalist nationalism. For this reason, an adequate analysis of the rise of Islamic identity should be situated in the historical context in which it occurred and in relation to the deepening of the crisis of the Kemalist will to civilization.

\section{The Impasse of the Political and the Possibility of "Democratic Opening"}

The search for a political community continues to be one of the significant sites that has formed and still gives meaning to Turkish politics in the 1990s. The present conjuncture of the Turkish political landscape is based upon a clash between the discourses of progress, secularism, and Reason and the discourses of traditionalism and anti-secularism. More precisely, the intersection between the decline of the hegemony of Kemalist nationalism and its definition of national identity and the rise of Islamic discourse as an effective articulating principle is one crucial site where the politics of identity is taking place in Turkish political life. Kemalism can no longer be considered an exclusive source of modernity. Instead there are alternative modernities, different articulations of globalization by different discourses, among which Islamism is primary.

Such an occurrence might be considered a positive, insofar as the emergence of alternative visions of modernity might be an indicator of multiculturalism and pluralism. However, as has been pointed out, the Islamic resurgence was mainly the outcome of "the weak state consensus." To the extent that the weak state consensus aims at minimizing state power rather than democratizing it, it does not contain any possibility of the democratic regulation of the state/society relations in which Islamic identity acts not as the essence of an alternative vision of society, but as an identity among others in a multi-cultural, plural setting.

For this reason, when analyzing the language of difference within the context of Islamic discourse, it is necessary to point to two crucial points of demarcation in order to avoid the trap of falling into the position of reversedessentialism that the discourse of political Islam, as in the case of the Welfare Party, employs. The first is that the crisis of national identity and the revitalization of the language of difference, while creating "the relative autonomization of economic activities, political groups, and cultural identities," and giving rise to "an autonomous societal sphere" which "has increasingly shifted (the focus of political practice) from the state to society" 
(Göle, 1994: 221-222), has also created essentialist identity claims as the primary reference-points of political discourse. In other words, the shift in focus towards civil society and the changing patterns of political discourse reproduced the same essentialist binary logic between secular versus antisecular, modern versus anti-modern, West versus anti-West, which the discourse of difference aims to repudiate. As we have witnessed in the recent debates over the question of Turkey's entry into the European Union, the issue of multi-culturalism and ethnicity, and the problem of democratization, the language of political Islam tends to be essentialist by promoting a fixed and coherent Islamic community. It does so by speaking the language of difference against what it regards as the totalizing secular national identity. In this way, the political Islamic discourse of the Welfare Party employs a nationalistic standpoint (the Muslim brotherhood) as it articulates its idea of "the just order and the just society" and employs communitarian political strategies. In this sense and in a paradoxical mode, the language of difference turns out to be as nationalistic and totalizing as the national identity to which it is radically opposed.

Ali Yapar Sarýbay in his important book, Postmodernity, Civil Society and Islam, captures and accounts for the paradoxical nature of the discourse of political Islam (Sarýbay 1994). For Sarýbay, the development of an autonomous societal sphere, which he calls "civil society," brings about a pluralist mode of organization of the state/society interactions that creates a space for the presence of Islamic discourse. In this way, civil society with its pluralistic institutional quality can be said to be a pre-condition for Islamic discourse to act as a discourse among others. Viewed in this way, it is internal to civil society and to the projects of democratizing the state/society interactions. However, with its operation based on the principle of tevhid, Islamic discourse necessarily aims at rendering plurality into singularity, that is, at reorganizing civil society as a homogeneous space. This paradox that characterizes the double-gesture of Islamic discourse as acting both for and against pluralism indicates that it would be mistaken to take for granted the shift towards civil society as a given and an unproblematic space that provides the foundational ground for democratization. That is to say, while employing the language of difference, the discourse of political Islam also operates as a totalizing discourse, attempts to reinscribe national identity on the basis of a return to Islamic principles, and employs a communitarian notion of political community as a organizing principle of state/society interactions. The result of this paradox is the promotion of the binary logic that situates the secular versus anti-secular polarization at the center of the 
political, which elevates the essentialist and communitarian claims to identity to the fore of the political agenda. ${ }^{16}$

The second point of demarcation is that the changing terms of political discourse from grand strategies of modernization to identity politics, while characterizing the crisis of Kemalist nationalism, did not mean the end of nationalism. On the contrary, nationalism has become the dominant ideology of the reorganization of civil society in the 1990s. As Tanýl Bora describes, the 1990s have exhibited "the dark spring of nationalism," especially of ethnic nationalism, which provided the ideological dressing of essentialist and communitarian claims to identity (Bora 1995). In other words, the emergence of the language of difference in the post-1980 coup period that had brought with it the shift to civil society resulted in "cultural struggles" in which each and every position put into service nationalist ideology to articulate its identity politics. ${ }^{17}$ A quick glance at these positions in cultural struggles, which have been organized around a binary logic, first between secular identity and Islamic identity, second between Turkish identity and Kurdish identity, and third between European identity and Turkish national identity, illustrates the resurgence of nationalist ideology in the form of (ethnic) identity politics in the 1990s. In these positions, it is nationalist ideology that made it possible for each to speak of its identity as if it is coherent, fixed, and constituted by an eternal essence, to redescribe the political through the practice of inclusion/exclusion and based upon the us/them distinction, and to pose itself as the foundational ground of political community. It is also nationalist ideology that enabled each to present itself as a unifying element of civil society. Thus, the discourse of political Islam attempted to unify different identities under the notion of Muslim brotherhood, Kemalist nationalism under the notion of secular identity, ethnic nationalist discourse under the notion of Turkish identity. As a result, essentialist claims to identity with a nationalist dressing marked and dictated the boundaries of the political in the 1990s.

What these two points of demarcation indicate is that Turkish politics in the 1990s has been and continues to be characterized both by the end of certainty, established by the Kemalist will to civilization through its economic, political, and cultural meta-narratives of modernization, and the presence of ambivalence in the way in which the state/society interactions are regulated and managed. On the one hand, we have the emergence of civil society as a site of political practice and the revitalization of political identities as discourses of difference that have created a new ground outside the terrain of Kemalist nationalism for thinking about the question of democracy. Thus, the democratization of the state/civil society interactions 
within the context of the recognition of differences as a challenge to the mono-culturalism of a republican search for national identity has become a significant term of political discourse of the 1990s. On the other hand, we have nationalist attempts to render the discourse of difference into an essentialist claim to identity, that have resulted in the organization of civil society through communitarian lines which prevents rather than enables the project of democracy to be consolidated. In using Aype Kadýoðlu's terminology, what marks the nature of Turkish politics in the 1990s is the ambivalent relationship between "the state in search of its nation" and the nation in search of its description (Kadýoðlu 1995).

The main conclusion, which can be extrapolated from the recognition of the presence of ambivalence as the marker of Turkish politics in the 1990s, is the following. If it is true that the possibility of the project of democracy has been impeded by the essentialist and communitarian claims to identity, then it is necessary to think of identity in relation to difference, to problematize any unifying and totalizing notion of identity, to put identity under an historical investigation to discover how it is constituted in relation to difference, that is, to recognize that the very unity of an identity is always achieved through the practice of the exclusion of other identities. To do so requires an epistemic shift to the problematic of identity/difference that sees identity in relational terms and resists its essentialist and communitarian articulation. It can be argued in this sense that the possibility of strengthening the project of democracy is present only when we recognize that each and every identity is constructed in relational terms and that the historical and discursive construction of every identity, whether it be national, ethnic or religious, gains unity and coherence not internally by an eternal essence but in relation to other identities. It is precisely because of this fact that the very possibility of the project of democracy is dependent upon the recognition of "the limit of an identity" as a way of resisting the essentialist and unifying notions of political community. ${ }^{18}$ The problematic of identity/difference therefore helps us not only to see how democratic possibilities can turn out to be possibilities for the articulation of essentialist claims to identity (as in the case of Turkey in the 1990s) but also, and more importantly, to develop effective strategies against essentialism, nationalism and communitarianism in the attempt to consolidate the project of democracy. Such strategies, I believe, are our only chance to break the weak state consensus, generating a suitable climate for the nationalist and communitarian visions of society, and to build a "democratic consensus" between state and civil society, identity and difference, and the self and the other. 


\section{Notes}

1. The difference that rewriting Turkish history based on "the woman question" makes has been very convincingly elaborated by N. Göle (1991). See also D. Kandiyoti (1991).

2. Whereas the rise of Islam and the re-emergence of Kurdish nationalism appear to be reactionary in terms of their essentialist appeal to political identity, feminist discourse aims at democratic reconstruction of civil society on the basis of the recognition of difference.

3. After the Supreme Court's decision to close the Welfare Party, a new party with the name of Virtue Party, was created and all the members of the Welfare Party were transferred to this new party. There is now a new case at the Supreme Court to shut down the Virtue Party, based on the claim that it is not a new party but just a replica of the Welfare Party. In this sense, the debate on the legitimacy of the Supreme Court decision still continues in Turkey.

4. These reforms include "the hat revolution," the reform of attire, the adaption of a civil code, "the alphabet reform," and religious reforms. For detail, see S. Yerasimos (1987).

5. For a different explanation of this practice of inclusion/exclusion, see L. Köker (1990). However, Köker's aim to challenge the claimed relationship between Kemalism and democracy seems to me to be problematic due to his reliance on the institutional conception of democracy as well as his complete neglect of the self/other question which I believe constitutes the basis of Kemalist nationalism.

6. Foucault defines governmentality as a way of subjugating differences to the domain of subjectivity. As he puts it, "In this sense, 'to be subject' is therefore 'to belong to,' in other words to behave as both an element of and an actor in a global process whose development defines the current field of possible experiences, inside of which the fact of being subject can only be situated." For detail, see M. Foucault (1979).

7. By locating secularism in a binary dichotomy between modernity and tradition, "the woman question" occupied an important space for Kemalist nationalism. The symbolic representation of women as the bearer of modernization was the strategy used against the anti-secular Islamic identity. The recognition of the place and the role of women in the public life of the republic as "educated social women," the adoption of the Swiss civil code in 1926 with which Turkish women gained new rights (the abolition of polygamy and repudiation), and the enfranchisement of women in 1934 were the policies by which the secular identity and its essential role for progress was justified against the anti-secular Islamic identity. It should be noted however that the rights and the reforms provided by the Kemalist elite, although they were based upon the recognition of the equality of Turkish men and women, were also obstacles to the emergence of an independent women's movement. In other words, the state-proclaimed gender equality rested on the symbolic representation of women as "symbolic pawns" rather than "political actors". For a detailed reading of the process of modernization from the angle of "the woman question," see N. Sirman (1989) and D. Kandiyoti (1989).

8. Here I am relying on Toprak's interpretation of Islam as a political force. See B. Toprak, (1987: 219).

9. For this theoretical extrapolation, I am drawing on David Campbell (1992). Campbell demonstrates such performative construction with reference to security discourse and foreign policy practice in the United States.

10. For a detailed analysis of the New Left and its relation to Kemalism, see A. Samim (1981). 
11. Similarly, the New Left discourse had no alternative vision of economic development. In fact, the vision of the economy it proposed was based also on import substitution industrialization with the state as the primary agent by which inequalities and uneven development were to be coped with in the name of dominated classes.

12. For the connection between the state and new right discourse, see M. Tünay (1993).

13. For an account of the changing nature of Turkish foreign policy toward the Middle East and especially with respect to Islamic capital, see B. A. Yepilada (1993).

14. Interestingly enough, the use of Islamic identity by the military regime in the form of the Turkish-Islam synthesis, in order to depoliticize society and eliminate the Left-discourse from the political sphere, which contributed to the resurgence of Islamic identity as a political force, ended in 1997, as the National Security Council declared that Islamic fundamentalism constitutes a fundamental threat to the secular regime. In this sense, the post-1980 Turkish modernization indicates the ambigious and the pragramatic role of Turkish military with respect to Islam.

15. For a very good account of this contradiction, see F. Birtek and B. Toprak (1993: 193201).

16. For an elaboration of the communitarian claim to identity and its ambivalent relation to the process of democratization, see E. F. Keyman (1995).

17. I borrowed the term "cultural struggle" from Sarýbay (1994).

18. I discussed in a detailed fashion the importance of the recognition of the limit of identity for the project of democracy in Keyman (1995 and 1996).

\section{References}

Abdel-Malek A. 1981, Social Dialectics, Albany: State University of New York Press.

Ahmad F. 1993, The Making of Modern Turkey, London: Routledge.

Anderson B. 1983, Imagined Communities, London: Verso.

Appadurai A. 1990, "Disjuncture and Difference in the Global Cultural Economy," in

Featherstone, M, Global Culture, London: Sage.

Berberoglu B. 1982, Turkey in Crisis, London: Zed Books.

Birtek F. and Toprak B. 1993, "The Conflictual Agendas of Neo-Liberal Reconstruction and the Rise of Islamic Politics in Turkey: The Hazards of Rewriting Turkish Modernity," Praxis International, 13, pp.192-211.

Bora T. 1995 Milliyetciligin Kara Bahari, Istanbul: Birikim.

Campbell D. 1992, Writing Security, Minneapolis: University of Minnesota Press.

Carrier J. G. 1992, "Occidentalism: the World Turned Upside-down," American Ethnologist, 19 , pp. 43-57.

Chatterjee P. 1986, Nationalist Thought and The Colonial World; A Derivative Discourse, The United Nations University: Zed Books.

Connolly W. 1996, The Ethos of Pluralization, Minneapolis: University of Minnesota Press. de Ferro C. 1995, "The Will to Civilization and its encounter with Laisser-Faire," Alternatives, 27, pp.89-103.

Eralp A. 1990, "The Politics of Turkish Development Strategies," in Finkel, A. and Sirman, N. (eds), Turkish State, Turkish Society, London: Routledge. 
Foucault M. 1979, “Governmentality,” Ideology and Consciousness, 6, pp.5-21.

Göle N. 1991, Modern Mahrem, Istanbul: Metis.

Göle N. 1994, "Toward an Autonomization of Politics and Civil Society in Turkey," in Heper,

M. and Evin, A. (eds) Politics in the Third Turkish Republic, Boulder: Westview.

Gülalp H. 1983, Gelipme Stratejileri Gelipme Ýdeolojileri, Ankara: Yurt Yayýnlarý.

Hall S. Held D. and McGrew T. (eds), 1992, Modernity and its Futures, Cambridge:Polity.

Heper M. 1985, The State Tradition in Turkey, North Humberside: The Eothen Press.

Kadýoðlu A. 1995, "Milletini Arýyan Devlet: Türk Milliyetçiliőinin Açmazlarý," Türkiye

Günlüठü, 33, pp.91-100.

Kandiyot, D. 1989, "Women and the Turkish State: Political Actors or Symbolic Pawns," in

Yuval-Davis, A. and Anthias, F. (eds), Woman-Nation-State, London: Macmillan.

Kandiyoti D. 1991, Women, Islam, and the State, London: Macmillan.

Keyder C. 1987, State and Class in Turkey, London: Verso.

Keyder C. 1993a, "The Dilemma of Cultural Identity on the Margin of Europe," Review, 16,

pp.19-33.

Keyder C. 1993b, "Türk Milliyetçiliðine Bakmaya Baplarken," Toplum ve Bilim, 62, pp.7-18.

Keyman, E.F. 1995, “Demokrasi. Toplululk, Fark,” Toplum ve Bilim, 66, pp.140-167.

Keyman, E.F. 1997, Globalization, State, Identity/Difference, New Jersey: Humanities Press.

Köker L. 1990, Modernlepme, Kemalism, and Demokrasi, Ýstanbul: Ýletipim Yayýnlarý.

Laclau E. 1996, Emancipation(s), London: Verso.

Landau J.M. (ed.), 1984. Ataturk and the Modernization of Turkey, Boulder: Westview Press.

Lewis B. 1968, Emergence of Modern Turkey, London: Oxford University Press.

Onis Z. 1997, "The political economy of Islamic resurgence in Turkey," Third World Quarterly, 4, pp. 743-766.

Robertson R. 1992, Globalization, London: Sage.

Robins K. 1996, “Interrupting Identities: Turkey/Europe,”Hall, S. (ed.), Questions of Cultural Identity, London, Sage.

Said E. 1979, Orientalism, New York: Vintage Books.

Said E. 1993, Culture and Imperialism, London: Chatto and Vindus.

Samim A. 1981, "The Left", in Schick I.C. and Tonak, A.E. (eds) Turkey in Transition, New York: Oxford University Press.

Sarýbay A. Y. 1994, Postmodernite, Sivil Toplum ve Ýslam, Ýstanbul, Ýletipim.

Sirman N. 1989, "Feminism in Turkey: A Short History,"New Perspectives on Turkey, 3, pp.134.

Spivak G. C. 1987, In Other Worlds, New York: Methuen.

Steinbach U. 1984, "The Impact of Ataturk on Turkey's Political Culture since World War II," in Landau, J.M (ed), Ataturk and the Modernization of Turkey, Boulder: Westview Press.

Toprak B. 1987, "The Religious Right," in Schick, I.C and Tonak, A.E. (eds), Turkey in Transition, New York: Oxford University Press.

Tünay M. 1993, “The Turkish New Right's Attempt at Hegemony,” in Eralp, A., Tunay, M., and Yepilada, B.A. (eds), The Political and Socioeconomic Transformation of Turkey, Westport: Praeger.

Yerasimos S. 1987, "The Monoparty Period" in Schick I.C. and Tonak E. A. (eds) Turkey in Transition.

Yepilada B. A. 1993, "Turkish Foreign Policy toward the Middle East," in Eralp, A., Tünay, M., and Yepilada, B.A. (eds), The Political and Socioeconomic Transformation of Turkey, Westport: Praeger. 